$\mathrm{Oz}$

Volume 35

Article 7

$1-1-2013$

\title{
Engaging Haiti: How Designers Facilitate Long-Term Disaster Recovery
}

Karl Johnson

Stacey McMahan

Follow this and additional works at: https://newprairiepress.org/oz

Part of the Architecture Commons

(c) $(1) \Theta$

This work is licensed under a Creative Commons Attribution-Noncommercial-No Derivative Works 4.0 License.

\section{Recommended Citation}

Johnson, Karl and McMahan, Stacey (2013) "Engaging Haiti: How Designers Facilitate Long-Term Disaster Recovery," Oz: Vol. 35. https://doi.org/10.4148/2378-5853.1516

This Article is brought to you for free and open access by New Prairie Press. It has been accepted for inclusion in Oz by an authorized administrator of New Prairie Press. For more information, please contact cads@k-state.edu. 


\title{
Engaging Haiti
}

How Designers Facilitate Long-Term Disaster Recovery

\author{
Karl Johnson and Stacey McMahan \\ Architecture for Humanity
}

There is a reason why Pétionville is the center of the recovery effort in Haiti. Its perch in the hills above Portau-Prince offers relative isolation from the metropolis, in addition to the mind-boggling panoramic views of the basin and bay from which that city has grown-qualities enough for establishing a national financial center, and some of Haiti's most luxurious hotels. From the conference rooms at the Montana, to the courtyards of the Karibe and the Kinam's poolside restaurant, Pétionville has, since the 2010 earthquake, become the focal point for international investors, conferences, discussions, and visions for Haiti's future.

The latest member of Pétionville's hotel pantheon opened last December-the Royal Oasis. A seven-story, 128-room edifice, the Oasis all but delivers the tourist paradise envisioned in Haiti's Grand Plan for re- construction, and should be a symbol of the country's robust recovery after a three-year struggle.

Of course, visitors today meet another reality when they tour Portau-Prince, the city in the basin. Most neighborhoods show little sign of improvement; thousands still live in tent camps, the slums are as dangerous as ever, and downtown businesses remain condemned skeletons occupied by squatters-not a mixed-use district served by shiny new streetcars. It seems forces are pulling Haiti and Haitians back to pre-quake conditions, if not worse.

The gap dividing these two perceptions of a recovering country is by no means irreconcilably divergent. Plenty of developments in Haiti attest that efforts and investments in recovery are being very successfully executed, albeit out of the public eye.

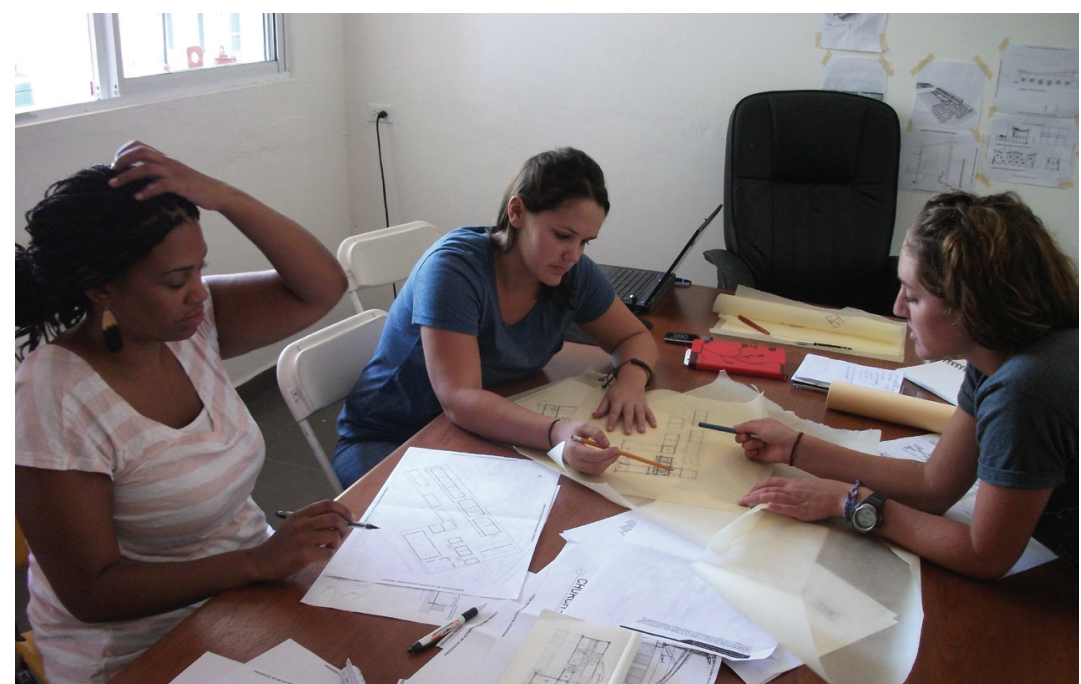

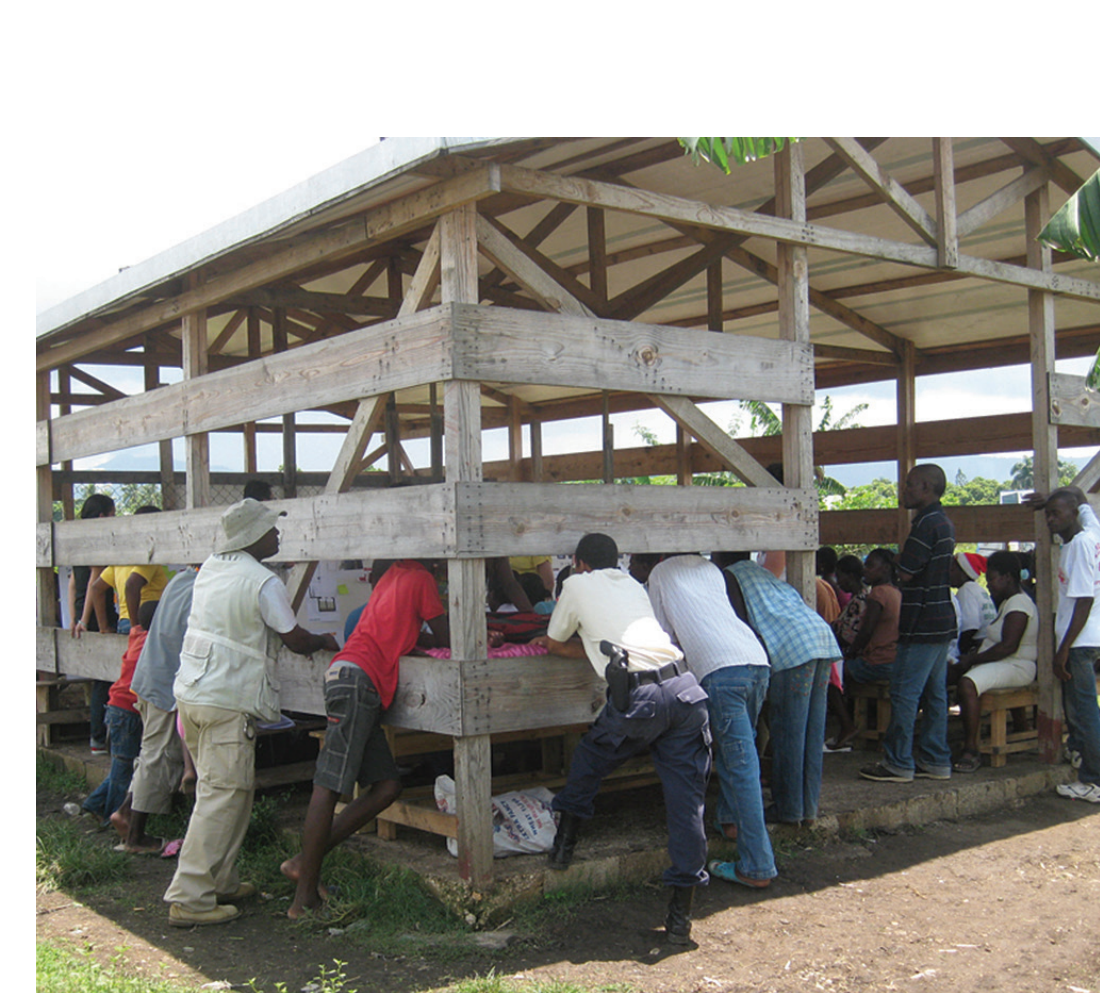

SPECTRUM OF DESIGN ENGAGEMENT BETWEEN PUBUC INTEREST DESIGNER AND LOCAL PROEESSIONAL INDUSTRY

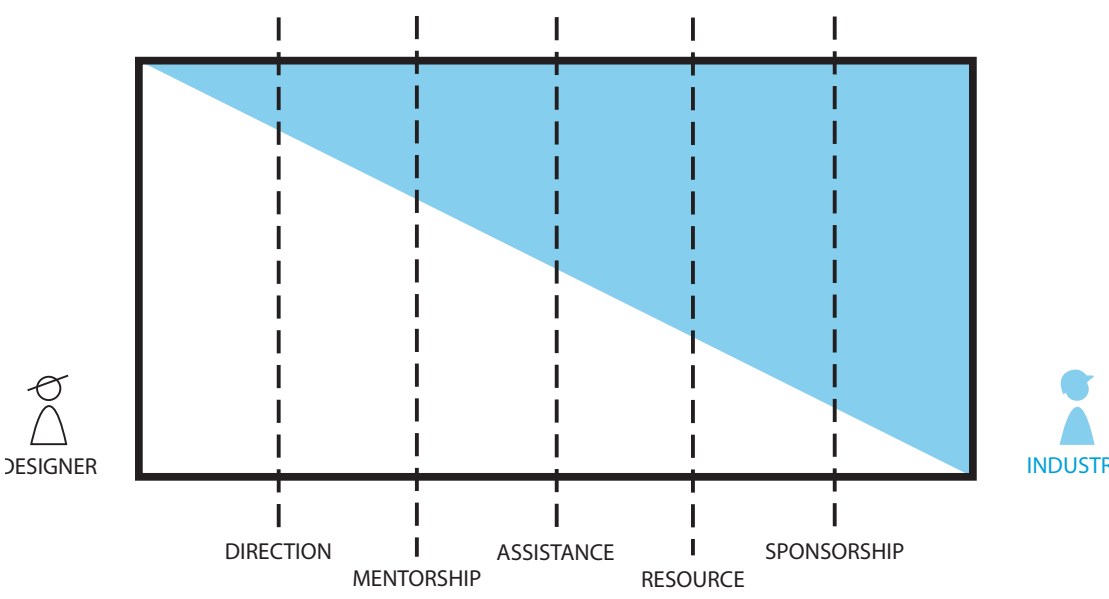


INVOLVEMENT OF STAKEHOLDERS - VILLA ROSA, PHASE 1 BETWEEN VILLA ROSA COMMUNITY, HAITIAN PROFESSIONAL INDUSTRY, AND FOREIGN DESIGNERS

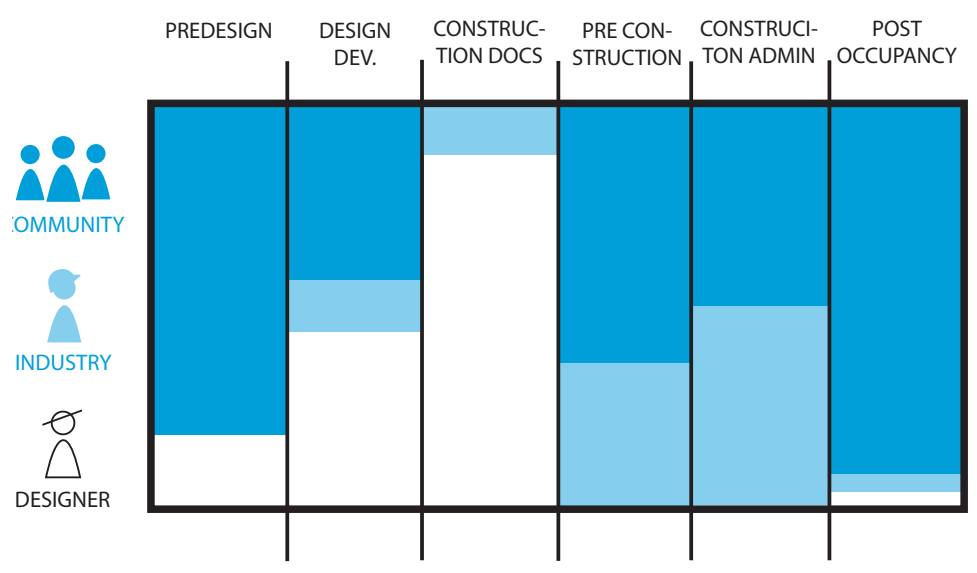

Some communities, rural and urban, are seeing their infrastructure and quality of life improve by leaps and bounds, often as a result of their own empowerment. The nature of these accomplishments does not attract headlines for being grandiose, sweeping reforms; neither do the complex challenges that have prevented a swift recovery. In fact it's the very low-key nature of this work that has made it successful: grassroots design and reconstruction, introduced by foreign organizations but directed by Haitian communities, establish precedence of a recovery that, little by little, is fostering strong foundations, resources, and built work supporting more sustainable communities. This seems to give all the credit to foreign organizations, when governmental partnerships are also needed for longterm structural stability.

A designer may be left to wonder: how on earth can I as an individual join in able outcome? connections and guide a process of sustainable development.

This has been the approach of Architecture for Humanity, a nonprofit bringing design and construction services to communities that cannot otherwise afford them. ${ }^{1}$ In clientdriven design, we do not work in a community where we have not been invited, and we defer to local wisdom and priorities in developing solutions specific to local needs. While there is a range of engagement required of designers in helping a community, its permission, enthusiasm and ownership of the project are critical to the project's success.

the milieu to assist? Is this possible? At what point do I engage a community to improve it? What precise service do I offer that is missing for the institution of a community-driven project? And how do I measure that my impact leads to a more sustain-

\section{Healthy Communities by Design}

Consider sustainability a pursuit of self-sufficiency within communities - whether that vehicle be material, energetic, or economic, whether it preserves human rights, livelihoods or identity as building blocks to a community's health. The aim of sustainable development at this scale is to secure the longevity of built improvements affecting the quality of life against health-threatening detriments. When communities lack an agency liaising critical needs to professional support, resources, or wisdom to achieve this transformation, a designer can establish these
In Haiti, Architecture for Humanity founded the Rebuilding Center ${ }^{2}$ to assess and execute the steps necessary to ensure communities in Haiti were "built back better." Projects engage local builders in construction and vocational training, and in the reconstruction of safe, strong, delightful, and permanent architecture, introducing international standards that were once foreign but welcomed by the local building industry. The Rebuilding Center works from similar programs established in Biloxi following Katrina ${ }^{3}$ and in post-tsunami Southeast Asia-the "one stop shop" model for design and construction services, coordinated at the grassroots level but establishing a precedent of enormous potential impact. smaller, and demand flexibility in
In grassroots work the victories start responding to unforeseen challenges. The team at the Rebuilding Center quickly realized that their long-term services were not only needed in the realm of architecture and training, but had to address systemic challenges otherwise making sustainable recovery impossible. Broader neighborhood reconstruction plans and sturdy economic foundations, as well as earthquake-resilient ones, were needed to tackle glaring issues such as sanitation and accessibility, stormwater drainage, construction financing and access to safe public spaces. The team broadened their services, launching a planning studio and an economic development studio to develop a set of tools suitable for holistic reconstruction. We are now managing more than twenty projects ranging from schools to community action plans to business surveys and regional mapping-different aspects of the complex challenge of sustainable development.

The diversity of work can nevertheless be broken down into simpler categories - of precisely how a designer engages a project, its end users, and the local professionals executing it (both parties equally referred to here as "clients"). On one extreme is the prescriptive solution, where the designer asserts their professional wisdom to unilaterally resolve a design challenge ("Private Interest Design”). In our work, the strongest influence a designer has is directing a client; though we are often in a role of a mentor, an assistant, at times a resource provider, or simply facili- 
tating sponsorship. The precise role depends on the nature of the project, and often several roles engage a project at its different stages, and for different project clients.

\section{Direction}

Haiti's disastrous earthquake was a result of systemic problems in building construction and quality enforcement. To quote our Resilience and Reconstruction Studio director, Eric Cesal, "The earthquake did not cause a disaster, it revealed one." Clearly Haitian builders did not suspect such an affront to their craft, and were wholly unequipped to modify it for either powerful seismic events or the day-to-day longevity expected of, but not present, in the way they were building. In this situation, it is incumbent upon the international community to instill construction wisdom and best practices, and to assist in reforming the nation's design and construction industry.

Rarely do prescriptive solutions correlate with public interest, but with such professional and technical imbalances and a large impact, direction is appropriate. This leaves the question of how to implement in a way the information can be adopted, understood, and employed.

In Haiti, masonry is a craft; masons approach each project working from experience, and not relying on construction drawing sets as we use them in the United States. One of the first challenges was adapting drawing sets to be better understood on site. The use of color to show rebar placement and views of 3D digital models to show steps of complex procedures (like foundation pours), help cut through the abstraction that Westerners take for granted. Intensive training precedes the construction phase, reviewing principles of better construction and taking builders through techniques from have found that despite the primarily one-directional nature of these sessions, builders find the instruction rewarding, and are proud to be able to improve their craft.

\section{Mentorship}

The Rebuilding Center follows construction administration through a team of Construction Outreach professionals that liaise between the job site and the main office, inspecting and correcting construction practices on each project, and reporting their progress. The Outreach program employs half a dozen Haitian engineers learning firsthand how to enforce and audit international construction standards with mentorship from the Rebuilding Center. Several members from the initial outreach team have been able to launch their own practices with the knowledge gained in this program.

Other rotating members of our office have profited from an intensive learn and work program, as volunteers at the Rebuilding Center. Each year dozens of designers work with the Center on a voluntary basis. They are usually young professionals with a few years experience and little prior exposure to nonprofit work. Over the course of a couple months these designers are not only digging into projects, but producing final drawings and documents with their work overseen by the Rebuilding Center staff. Volunteers tend to return, eager to share their experiences, frequently staying involved within the realm of humanitarian design.

\section{Assistance}

The charrette is an intensive workshop organized by the design team to structure engagement and feedback from members of a project's community or stakeholders. It is perhaps the most familiar tool of client engagement, and is generally valuable for everyone involved, provided the charrette is properly calibrated. Through modeling exercises, mapping and focused dialog, participants discover their priorities and make the first steps in addressing them. Charrette outcomes build an unmatchable set of inputs and sense of ownership, in some cases empowering a community to carry the project through itself.

In our school projects we begin design by working with faculty and students over a series of workshops. At Coeur Immacule de Marie, these sessions guided discussion of project's constraints through team building, prioritization, and modeling. ${ }^{4}$

The informal urban neighborhood of Villa Rosa in Port-au-Prince ${ }^{5}$ is an example of the inherent possibilities of a tactically structured series of workshops. Community engagement involved neighborhood infrastructural mapping bookended by
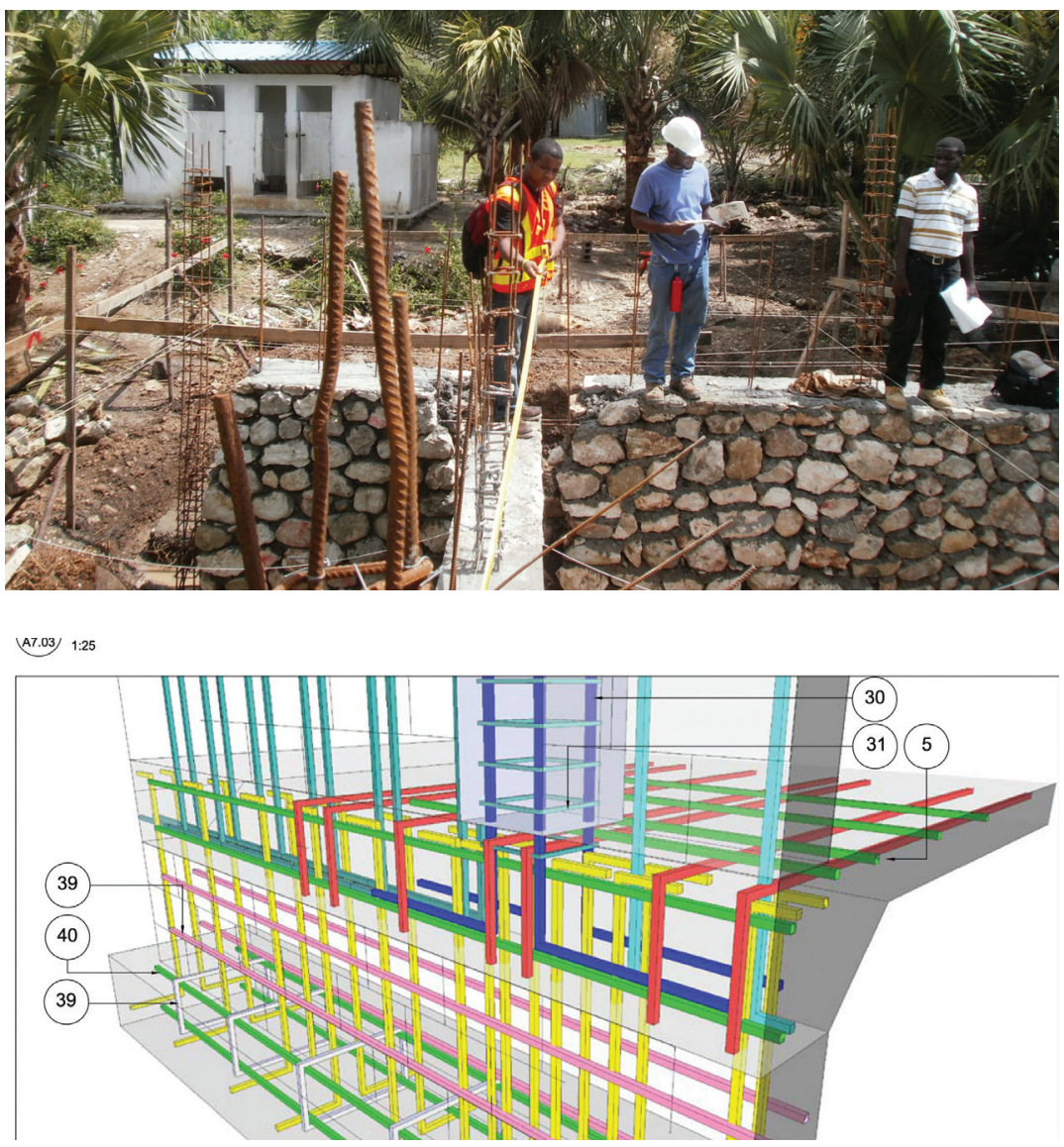

Drawings sets were created using color for better understanding on site door-to-door surveys and validation meetings. Next, a series of charrettes brought dozens of residents together to discuss critical issues like access, drainage, and sanitation. While the Rebuilding Center applied seasoned professional wisdom to the products of these charrettes, it was the Villa Rosa community itself that worked with these documents to hire contractors, purchase materials, and see through small-scale built interventions that have made their neighborhood safer, cleaner, and easier to navigate. Since the completion of Villa Rosa's initial phase, its community engagement approach is being replicated for 16 similarly informal neighborhoods around Port-auPrince. This is an ideal outcome of our work

\section{Resource Provision}

Designers can develop toolkits, man- 
uals, or other resources for the client's use before a project commences, or before the roles of a project are even established. In some cases these can streamline a project timeline; in other cases these documents are critical companions to navigate complex systems or esoteric languages the client is expected to understand.

Before we had eyes on the ground, weeks after the earthquake, we assembled a Rebuilding 101 manual for concrete block construction that could be printed, in the event unskilled Haitians started rebuilding without oversight. Designed for universality the manual relied on graphics, diagrams, black ink, and letter-sized paper and was translated in four languages, including Kreyole ${ }^{6}$.

These days Property Law Working Group is tackling a terrific quagmire in reconstruction, the bureaucracy surrounding land ownership claims. The Group has worked this past year analyzing the structures in place for ascertaining rights to land parcels when they are in dispute. In February 2013 they released a manual any Haitian can use to navigate the labyrinthine legal system with their claim. The Haiti Land Transaction Manual is the first step of a larger campaign to reform how property tenure is recognized in Haiti.?

\section{Sponsorship}

Frequently a client's needs for realizing a project are simply the financing to do so, or the matchmaking of their skills to a project seeking them. A designer can sponsor such endeavors with little further intervention required on their part for execution.

This level of engagement opens doors to programs that would not otherwise be proposed as part of disaster recovery. Business rebuilding grants have been difficult to establish in Haiti, largely because local banks knew no precedent for disbursing micro-loans. The Rebuilding Center facilitated business and economic corridor (street-oriented business district) surveys, organized meetings, and made inroads to get a business financing program off the ground. The program currently has five participating local banks working with qualified small- and medium-sized Haitian businesses.

In 2011 the Civic Arts for Haiti Schools program granted Haitian artists funding to create sculpture installations for rebuilt or rebuilding schools. It is easy to question the necessity of such a program, yet expression, camaraderie, culture, and pride-byproducts of civic artwere a critical element for a holistic recovery rarely included in rebuilding efforts. The simply structured Civic Arts grant program allowed a dozen mostly unemployed local artists to develop cultural anchors benefitting hundreds of students.

\section{Engagement Levels Along a \\ Project Timeline}

As we outline a spectrum of designer engagement in a project, it is important to note that this relationship will shift over that project's course, and its different stages of development. Direction, Mentorship, Assistance, Resource Provision, and Sponsorship may all find place in a project's timeline. We should break our "client" out into the community that will have ultimate use of a project and the local industry recruited to bring the project to completion.

We can quickly analyze the contributive forces at play in two of our projects: École Baptiste Bon Berger,

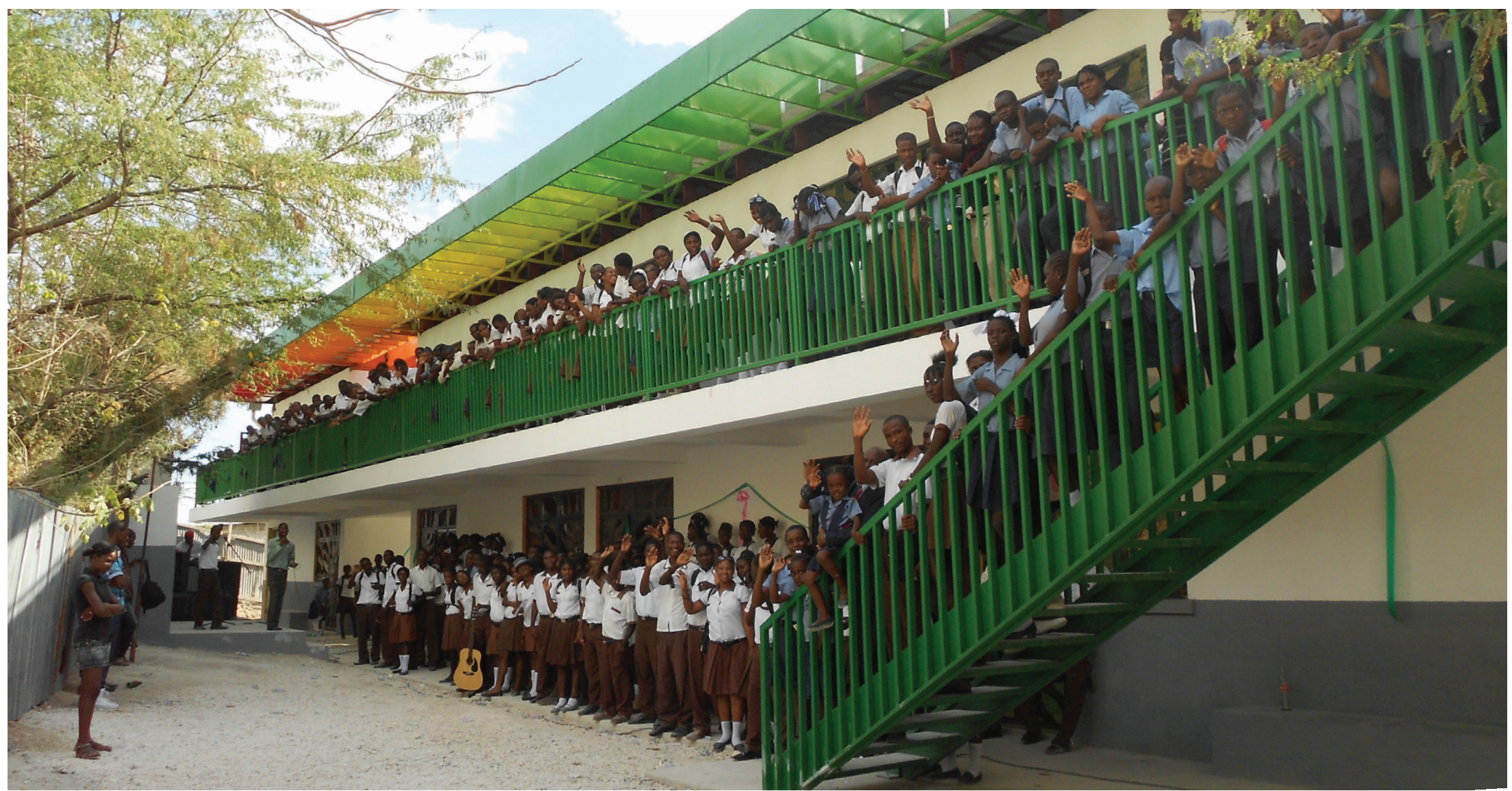

Opening Day at Montrouis School 
"Montrouis School," and the initial phase of Villa Rosa previously mentioned.

The Montrouis School, developed in partnership with the school's supporters and headmaster, was an early project for the Rebuilding Center, and an opportunity to put all of the Rebuilding Center values into play. ${ }^{8}$ In predesign, we had conversations at length with members of the school to envision how a new school would look and what their needs were. Design development was completed and we received feedback from the stakeholders; meanwhile, refinements continued to be made on construction documents to make them more legible for contractors, with the drawings going out to bid before construction.

When a contractor was selected, we partnered with nonprofit Build Change to hold construction training on site, heavily involving the construction crew. The construction crew started building with oversight from the Outreach team, who wore both "designer" and "industrial" hats. In this stage we also subcontracted decorative elements to be made by local metalsmiths; the craftsman and construction industries benefited from construction administration at Montrouis. While the students and faculty are the end users of the project, the Civic Arts sculptural centerpiece also supports the artist who created it. The completed school equally bears testament to the quality
In the initial phase of the Villa Rosa Community Action Plan, designs were strengthened by further development at the Rebuilding Center, and through its community engagement tools-to the extent that the project designs were self-executed by the community. As noted, this form of collaboration carries a powerful impact for the clients involved, who needed a minimum amount of intervention to leverage important improvements in their neighborhood.

\section{Transition}

The final step for Architecture for Humanity at the Rebuilding Center is to transition ownership and operation to a wholly Haitian capacity. This assures that the Center can perpetuate itself without the presence of the founding party. After three years, this transition is underway; because a local network has been built, Haitian staff is filling administrative roles, and the Center is pursuing Haitian Non-Governmental Organization status. Sustainability comes full circle when a satellite office can source its own projects, funding, and support, and carries on under its own inertia.

\section{Mission Accomplished?}

Transitioning out leaves foreign public interest designers to disengage from their post and move on. It's a privilege to work in Haiti as designers, and while there are many differences between how Haiti and the United States, Canada, or Europe operates, the above definitions of client engagement carry a certain universality. Back at our climate-controlled offices

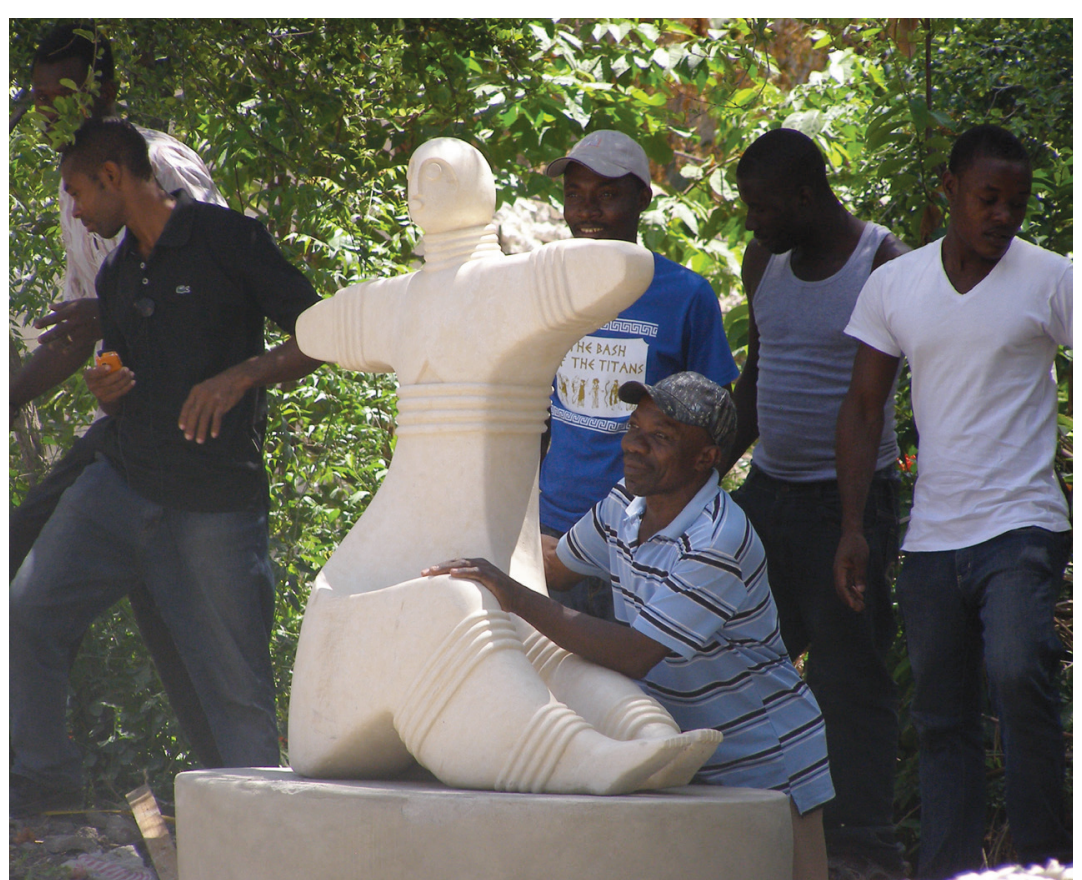

Civic Arts sculptural centerpiece

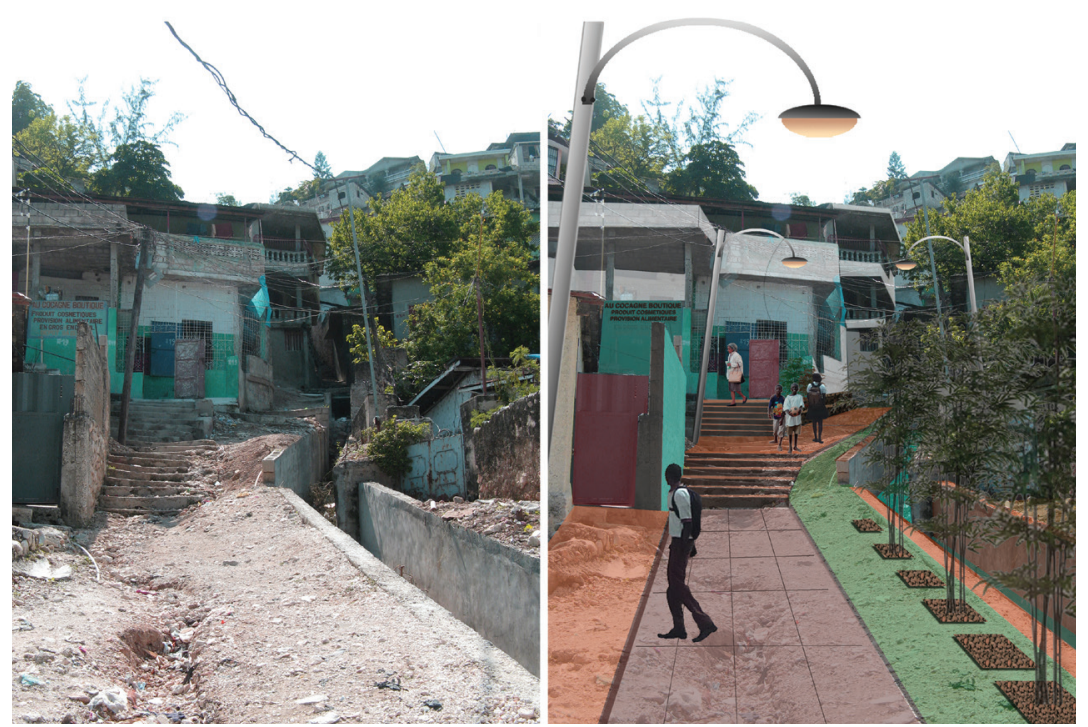

Villa Rosa priority pathway; before, left and after, right 
in our hometowns, we see issues in our backyards that can be addressed through design, and we have a toolkit to assess how the invisible work of a designer can make lasting local improvements.

In Haiti, the Royal Oasis Hotel may well be the standard bearer for new business and industry, but after only three years these signs are still too hard to read. However, promise exists today in the grassroots development efforts that may after all determine the strength of the foundations of reconstruction.

\section{Notes}

1. Architecture for Humanity, http://architectureforhumanity.org.

2. “Centre de Reconstruction, Port-au-Prince, Haïti," WorldChanging, http://openarchitecturenetwork.org/projects/haiti_reconstruction.

3. "New East Biloxi Coordination Relief and Redevelopment Agency," WorldChanging, http:// openarchitecturenetwork.org/projects/669.

4. Johnson, Karl, "Girls at CIM co-design their new school," Architecture for Humanity, last modified October 12, 2012, http://architectureforhumanity.org/updates/2012-10-12-girls-atcim-school-co-design-their-new-school.

5. Johnson, Karl, "Intense Collaboration: Community Planning and Urban Acupuncture in Villa Rosa, Port-au-Prince," Architecture for Humanity, last modified June 18, 2012, http://architectureforhumanity.org/updates/2012-06-18-intense-collaboration.

6. "Rebuilding 101 Manual," WorldChanging, http://openarchitecturenetwork.org/projects/ rebuilding101.

7. Johnson, Karl, “Context to Reconstruction: Haiti's Property Law Working Group," Architecture for Humanity, last modified October 13, 2012, http://architectureforhumanity.org/updates/2012 10-13-context-to-reconstruction-haitis-property-law-working-group.

8. Reilly, Gerry, "Collège Mixte Le Bon Berger, Montrouis", Architecture for Humanity, last modified February 10, 2012, http://architectureforhumanity.org/updates/2012-02-10-collège-mixte-lebon-berger-montrouis-complete.

9. Johnson, Karl, "Summer Credit - Civic Arts accomplishments in Haiti Schools," Architecture for Humanity, last modified August 22, 2012, http://architectureforhumanity.org/updates/2012 08-22-summer-credit.

\section{Image Credits}

Page 32: (Left) Schendy Kernizan, Page 32: (Bottom Right) Nancy Doran, Page 34: (Top) Carl Harrigan, Page 34: (Bottom) Haiti Rebuilding Center, Page 35: Gerry Reilly, Page 36: (Top) Rene Lafontant, Page 36: (Bottom) Nazanin Mehregan, Page 37: (Top) Gerry Reilly, Page 37: (Middle \& Bottom) Stephen Sun
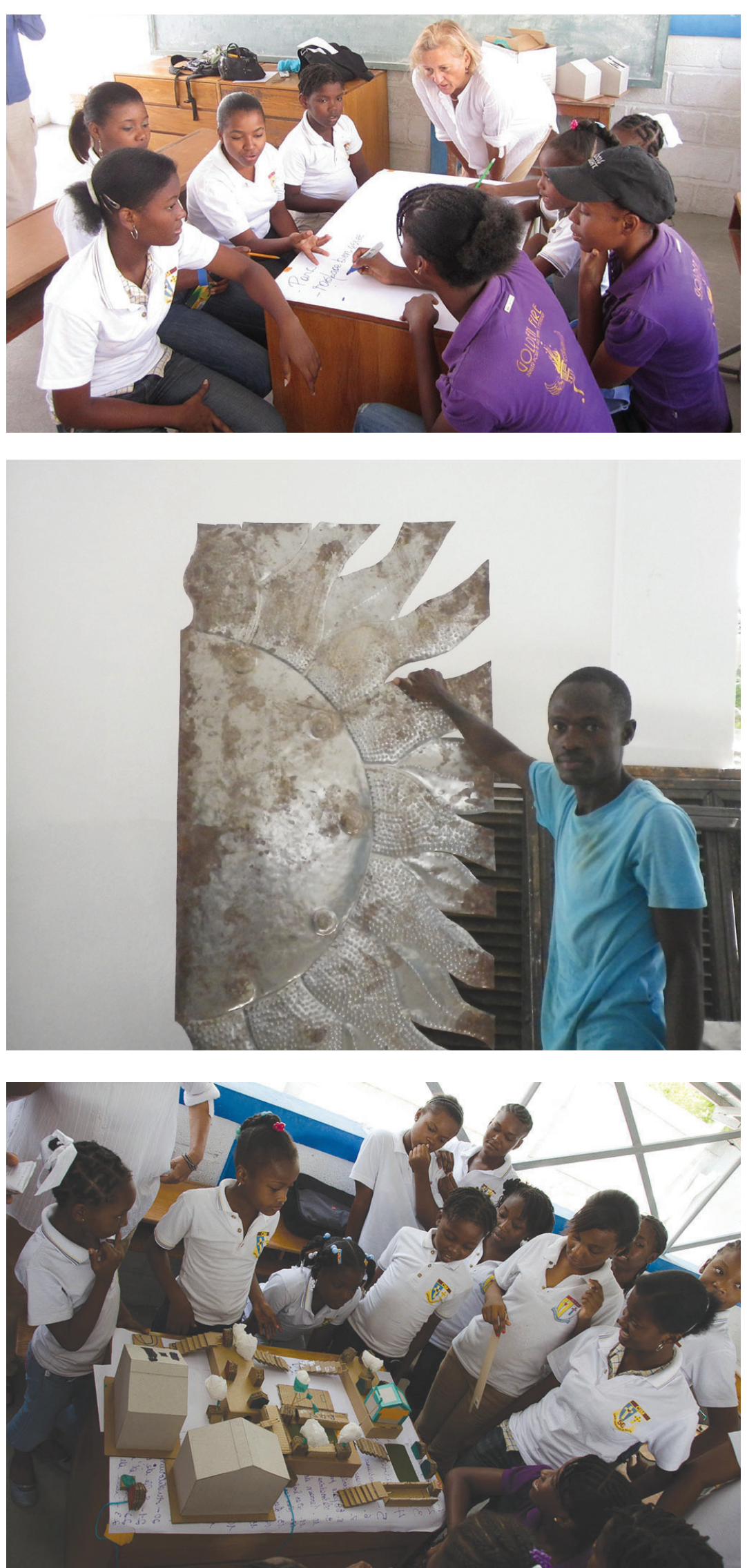